\title{
EVALUATION OF ANTIOXIDANT ACTIVITY AND MINERALS VALUE FROM WATERCRESS (Nasturtium officinale R.Br.)
}

\author{
G. Haro ${ }^{1}$, I. Iksen ${ }^{1, *}$, R.M. Rumanti' ${ }^{2}$, N. Marbun², R. P. Sari ${ }^{2}$ \\ and R. P. J. Gultom ${ }^{3}$ \\ ${ }^{1}$ Department of Pharmaceutical Chemistry, Universitas Sumatera Utara, \\ Medan-20155, Indonesia \\ ${ }^{2}$ Department of Biological Pharmacy, Universitas Sumatera Utara, Medan-20155, Indonesia \\ ${ }^{3}$ Department of Pharmacy, STIKes Imelda, Medan-20239, Indonesia \\ *E-mail: ikseniksen08@gmail.com
}

\begin{abstract}
Watercress (Nasturtium officinale R.Br.) is an annual plant from Brassicaceae family. It is easy to grown and often widely at a small river, pond, swamp and shallow lake. It is not only consumed as a vegetable but also used for the treatment of anticancer, antidiabetes, antiallergy and tuberculosis. From all of these health benefits, this study was carried on to evaluate exposed of antioxidant activity and minerals value as the pharmaceutical and nutritional sources. Antioxidant efficacy of various organic solvent extracts from watercress was evaluated by using DPPH free radical scavenging assay. Determination of minerals content was using the atomic absorption spectrophotometry assay. Methanolic extract of watercress showed the best antioxidant activity rather than ethyl acetate and hexane extracts. Watercress also contained a lot of minerals such as calcium, potassium, sodium and magnesium which are very important for human body. From this study, it could be concluded that watercress is a good promising pharmaceutical and nutritional sources.
\end{abstract}

Keywords: Watercress, Antioxidant, DPPH, Mineral, Extract, Spectrophotometry.

(C) RASĀYAN. All rights reserved

\section{INTRODUCTION}

Watercress (Nasturtium officinale R.Br.) is an aquatic and yearly plant of the Brasicaceae family. ${ }^{1}$ This plant has excellent benefits and nutrients. These leafy vegetables have mineral and vitamin content that is quite complete. Caloric content is very low and contains enough fiber. Therefore, it is very good for those who undergo low-calorie diet. Watercress can be used to maintain digestive and kidney health, cleanse toxins in the body, inhibit the development of cancer cells, treat a sore throat, treat tuberculosis and treat scabies. These vegetables can be eaten fresh or boiled and sauteed. It tastes very unique, bitter, slightly sweet and sour. ${ }^{2}$

Watercress is rich in many vitamins such as vitamin $\mathrm{C}(62 \mathrm{mg} / 100 \mathrm{~g}$ servings $)$, Vitamin A $(420 \mu \mathrm{g} / 100 \mathrm{~g}$ servings (converted from $\beta$-carotene content)), vitamin E (1.46 mg / $100 \mathrm{~g}$ servings), vitamin K (250 $\mathrm{g}$ / $100 \mathrm{~g}$ servings $),{ }^{3}$ gluconasturtine, ${ }^{4}$ folate acid, iodine, iron, protein, and calcium. ${ }^{5}$ Watercress contains flavonoid compounds (quercetin and kaempferol) which can act as antioxidants, ${ }^{6}$ gluconasturtine and minerals. Because of the excellent benefits and nutrients of watercress, watercress has been used for medical treatment since ancient times.

Reactive oxygen species (ROS) are highly reactive species, due to the presence of unpaired valence shell electrons. Free radicals or reactive oxygen species are regularly and continuously produced as byproducts of normal cellular metabolism in aerobics. Free radical chain reactions are usually produced in the mitochondrial respiratory chain, liver mixed functions and by drugs or xenobiotic such as synthetic pesticides. $^{7}$ The oxidative injury now appears the fundamental mechanism underlying a number of human neurologic and other disorders such as neurodegenerative disorders e.g. Down's syndrome, Parkinson's 
disease, Alzheimer's disease, Multiple sclerosis, inflammation, viral infection, , gastrointestinal inflammation, ulcer, an autoimmune disorder, mutagenesis, and carcinogenesis. ${ }^{8-10}$

Therefore proper prevention and treatment efforts are needed to reduce the degenerative diseases. Diet with high consumption of antioxidant-rich fruits and vegetables significantly reduces the degenerative diseases. One of the useful promising plants is watercress (Nasturtium officinale R.Br.). For ages, watercress is well known for a wide variety of medicinal uses. By keeping in view all the properties of antioxidants, present research work was designed for the isolation of bioactive components from watercress extracts and assessment of antioxidant and determination of minerals value as nutritional source, Therefore, the aim of the present study was to investigate the potential pharmaceutical and nutritional sources from watercress.

\section{Plant Material Preparation}

\section{EXPERIMENTAL}

Fresh watercress was collected from the local market in Medan (North Sumatera, Indonesia) and authenticated by the Indonesian Institute of Sciences: Research Center For Biology. A voucher specimen was collected and deposited in the Pharmacognosy Laboratory, Faculty of Pharmacy, Universitas Sumatera Utara.

\section{Preparation of Extracts}

Extraction was done by a stratified maceration method that has been modified using organic solvent based on the multilevel polarity from low to high polarity solvent (hexane, ethyl acetate and ethanol). $900 \mathrm{~g}$ of powdered lotus leaf are macerated in advance with the solvent hexane for 3 days, then filtered, do it continuously until the filtrate obtained is clear and colorless. The resulting dregs do the same thing for the solvent of ethyl acetate and methanol. ${ }^{11}$

\section{Preliminary Phytochemical Screening}

Phytochemical screening carried out on various watercress extracts included examing the chemical metabolites constituent of alkaloids, flavonoids, glycosides, tannins, triterpenoids, and steroids. ${ }^{12-14}$

\section{Free Radical Scavenging Activity Determination}

The antioxidant activity of the different watercress extracts was measured using the stable 1,1-diphenyl-2picryl hydrazyl radical (DPPH) by Blois method. ${ }^{15}$ The different watercress extracts solution were added, at an equal volume. $0.5 \mathrm{mM}$ DPPH was added to each sample. After incubation for $30 \mathrm{~min}$ in the dark condition and absorbance was taken at $515.5 \mathrm{~nm}$ and calculated the \% inhibition of DPPH radical. ${ }^{16-19}$ The test was carried out in triplicate. Ascorbic acid was used as standard controls. $\mathrm{IC}_{50}$ values denote the concentration of the sample, which is required to scavenge $50 \%$ of DPPH free radicals.

\section{Mineral Values Determination Sample Ashing}

The sample was weighed $25 \mathrm{~g}$, put into a porcelain crucible, dried over a hot plate then ashed in a furnace with an initial temperature of $100^{\circ} \mathrm{C}$ and slowly raised to $500^{\circ} \mathrm{C}$ at $25^{\circ} \mathrm{C}$ intervals every 5 minutes. The ashing process was carried out for 36 hours and then transferred to the desiccator. The ashes were dripped with 10 drops of demineralized water and added $4 \mathrm{ml}$ of $\mathrm{HNO}_{3}(1: 1)$. Then evaporated on a hot plate until dry. The porcelain cruses were put back into the furnace and held for 1 hour at a temperature of $500^{\circ}$ $\mathrm{C}$, then cooled.

\section{Procedure of Sample Solution}

The ash then dissolved in $5 \mathrm{ml}$ of $\mathrm{HNO}_{3}(1: 1)$ and then transferred to a $100 \mathrm{ml}$ volumetric flask, dilute it using demineralized water,add to the line. The solution was then filtered with Whatman no. 42. The first filtrate was removed $5 \mathrm{ml}$ to saturate the filter paper and then the filtrate was then collected in the bottle. This filtrate was used as a sample solution for quantitative minerals determination using atomic absorption spectrophotometry. ${ }^{20}$ 


\section{Calibration Curves of Potassium, Calcium, Sodium and Magnesium Potassium}

Measured each absorbance of a standard solution of potassium $2.0 ; 4.0 ; 6.0 ; 8.0 ;$ and $10.0 \mu \mathrm{g} / \mathrm{ml}$ with Atomic Absorption Spectrophotometer at $766.5 \mathrm{~nm}$ wavelength.

\section{Calcium}

Measured each absorbance of a standard solution of calcium $1.0 ; 2.0 ; 3.0 ; 4.0$ and $5.0 \mu \mathrm{g} / \mathrm{mL}$ with Atomic Absorption Spectrophotometer at $422.7 \mathrm{~nm}$ wavelength.

\section{Sodium}

Measured each absorbance of a standard solution of sodium $0.2 ; 0.4 ; 0.6 ; 0.8$; and $1.0 \mu \mathrm{g} \mathrm{ml}$ with Atomic Absorption Spectrophotometer at $589.0 \mathrm{~nm}$ wavelength.

\section{Magnesium}

Measured each absorbance of a standard solution of magnesium $0.2 ; 0.4 ; 0.6 ; 0.8$; and $1.0 \mu \mathrm{g} / \mathrm{ml}$ with Atomic Absorption Spectrophotometer at $285.2 \mathrm{~nm}$ wavelength.

\section{Determination of Potassium, Calcium, Sodium and Magnesium in Watercress}

The sample solution was then measured for absorbance by using an atomic absorption spectrophotometer which had been conditioned and regulated in which the determination of levels for potassium, calcium, sodium and magnesium was performed at wavelengths of $766.5 \mathrm{~nm}, 422.7 \mathrm{~nm}, 589 \mathrm{~nm}$ and $285.2 \mathrm{~nm}$, respectively with an air-acetylene flame. ${ }^{20,21}$

\section{Statistical Analysis}

Antioxidant activity and mineral values were expressed as mean \pm SD. The significance of antioxidant activity values of the different watercress extracts was compared by ANOVA followed by Duncan's test. The mineral content obtained from the measurement of the sample solution was statistically analyzed and to determine the mineral content in the sample with a $99 \%$ confidence interval.

\section{Phytochemical Screening}

\section{RESULTS AND DISCUSSION}

The phytochemical screening result is shown in Table-1. Phytochemical screening revealed that phytochemical compounds such as alkaloids, flavonoids, saponins, tannins, steroids, anthraquinone were present in watercress.

Table-1: Phytochemical screening result of hexane fraction from papaya male flower.

\begin{tabular}{c|c|c|c|c}
\hline No & Phytochemical Screening & $\begin{array}{c}\text { Hexane } \\
\text { Extract }\end{array}$ & $\begin{array}{c}\text { Ethyl acetate } \\
\text { extract }\end{array}$ & $\begin{array}{c}\text { Methanol } \\
\text { Extract }\end{array}$ \\
\hline 1 & Alkaloids & - & - & - \\
\hline 2 & Flavonoids & - & + & + \\
\hline 3 & Glycosides & - & + & - \\
\hline 4 & Anthraquinone glycosides & - & - & - \\
\hline 5 & Sapnonins & - & - & - \\
\hline 6 & Tannins & - & + & - \\
\hline
\end{tabular}

\section{Free Radical Scavenging Activity of DPPH}

In this study, the antioxidant activity of watercress extracts was measured using the DPPH assay. All the data are presented in the Table-2 and Fig.-1. Free radicals are known to be a major factor in biological damages, and DPPH has been used to evaluate the free radical-scavenging activity of natural 
RASĀYAN J. Chem.

Vol. 11 | No. 1 |232-237 | January - March | 2018

antioxidants. ${ }^{22,}{ }^{23}$ In the present study, the best $\mathrm{IC}_{50}$ value was shown in methanol extract, followed by ethyl acetate and hexane extract.

Table-2: Comparison of DPPH radical scavenging activity of various watercress extracts.

\begin{tabular}{c|c|c|c}
\hline Solvent & Concentration $(\mathrm{ppm})$ & $\mathrm{IC}_{50}(\mathrm{ppm})$ & Scavenging $(\%)$ \\
\hline Hexane extract & 400 & $712.81 \pm 4.5^{* \mathrm{a}}$ & 26.45 \\
\hline Ethyl acetate extract & 400 & $405.01 \pm 1.5^{*} \mathrm{~b}$ & 49.31 \\
\hline Methanol extract & 400 & $273.14 \pm 2.7 * \mathrm{c}$ & 69.55 \\
\hline Ascorbic acid & 8 & $3.97 \pm 0.58$ & 95.63 \\
\hline
\end{tabular}

Values are given as mean \pm SEM for five mice in each group. $*_{\mathrm{a}}, *^{*} \mathrm{~b},{ }^{*} \mathrm{c}$ were significance compared with ascorbic acid group.

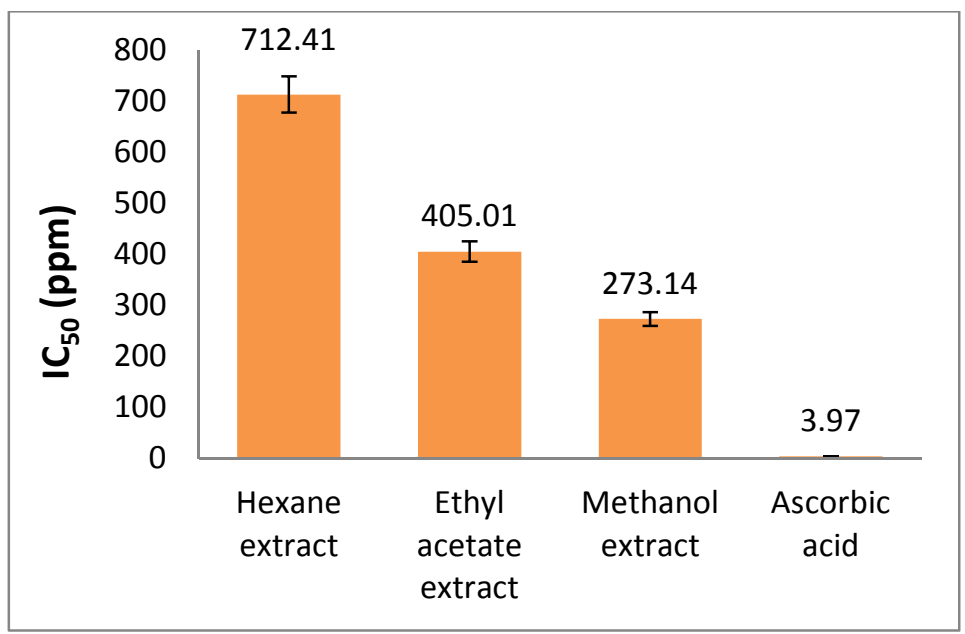

Fig-1: The $\mathrm{IC}_{50}$ value of various watercress extracts.

Methanol is efficient and the most widely used to extract antioxidant components including the phenolic components. ${ }^{24}$ According to Cakir (2006) ${ }^{25}$ the antioxidant activity if the extracts obtained by polar organic solvents such as methanol were also greater than those of the extracts obtained by non-polar organic solvents such as hexane and chloroform. It can suggest that the polar compounds like phenolic are mainly responsible for the antioxidant activity. ${ }^{26}$

\section{Calibration Curves of Potassium, Calcium, Sodium and Magnesium}

The regression equation for each mineral were $Y=0,040354 X+0,002962$ for potassium, $Y=0,035171 X$ $+0,004710$ untuk calcium, $Y=0,116600 X+0,001467$ untuk sodium, dan $Y=0,386986 X+0,003024$ for magnesium. The correlation coefficient for each minerals calibration curve were 0.9996, 0.9995, 0.9997 and 0.9995 respectively can be accepted which the value should not smaller than $0.995 .{ }^{21}$ The coefficent value showed a linear relationship between the concentration and absorbance. All of the calibration curves from the minerals are presented in Fig.-2.

\section{Watercress Mineral Contain}

The result of the mineral determination in watercress showed that watercress had a good mineral value especially the macro mineral such as the potassium, calcium, sodium, and magnesium which are presented in Table-3.

Table-3: The potassium, calcium, sodium and magnesium level in fresh watercress

\begin{tabular}{c|c}
\hline Mineral & Mineral level $(\mathrm{mg} / 100 \mathrm{~g})$ \\
\hline Potassium & $481.795 \pm 2.40$ \\
\hline
\end{tabular}


RASĀYAN J. Chem.

Vol. 11 | No. 1 |232-237 | January - March | 2018

\begin{tabular}{c|c}
\hline Calcium & $74.980 \pm 0.139$ \\
\hline Sodium & $11.699 \pm 0.166$ \\
\hline Magnesium & $15.687 \pm 0.157$ \\
\hline
\end{tabular}

Minerals are important for human body. The balance of mineral ions in the body regulates metabolic processes, acid-base balance, osmotic pressure, helps transport important compounds of membraneforming, some of the minerals are used to the constituents of tissue-forming. Indirectly, many minerals play a role in the growth process. The role of minerals in our bodies is related to each other, and the deficiency or excess of one mineral will affect the working of other minerals. ${ }^{1,27}$
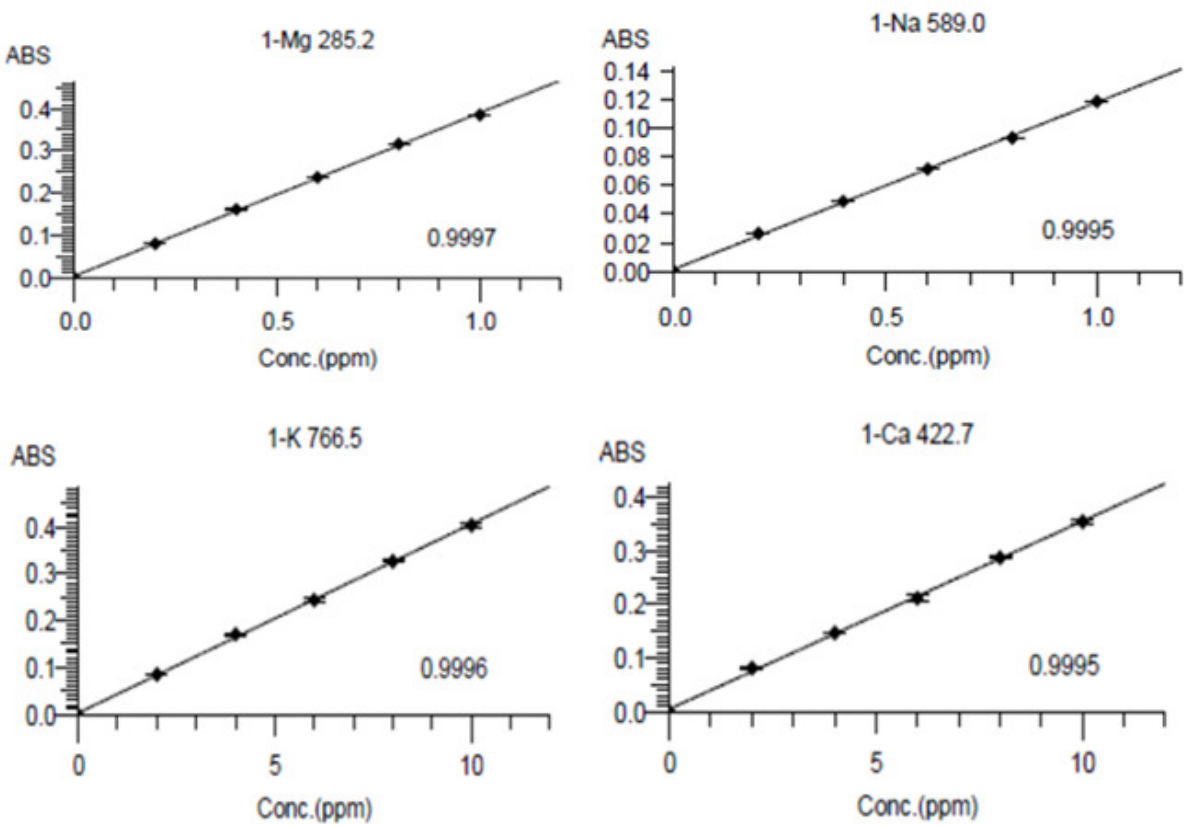

Fig-2: The calibration curves of magnesium, sodium, potassium and calcium

\section{CONCLUSION}

From overall, an evaluation study of antioxidant and mineral contents of watercress (Nasturtium officinale R.Br.) could be concluded that watercress is an excellent source of antioxidant and mineral sources. Watercress could be used as a promising pharmaceutical and nutritional sources.

\section{ACKNOWLEDGEMENT}

The author wishes to thank Jessica Novia, Jessica Novia (Universitas Sumatera Utara, Indonesia), and Suthinee Theerachetmongkol (Mahidol University, Thailand) for consultant and helpful support in doing the research and editing the manuscript.

\section{REFERENCES}

1. J. Novia, B. Pharm. Thesis, Department of Pharmaceutical Chemistry, University of Sumatera Utara, Medan, North Sumatera, Indonesia (2015).

2. L. Lingga, Cerdas Memilih Sayuran, PT Agro Media Pustaka, Jakarta, p.335-340 (2012).

3. http://watercress.co.uk/wp-content/uploads/2012/01/superfood1.pdf

4. N. Shahroki, M.K. Hadad, Z. Keshavarzi, M. Shabani, Pakistan Journal of Physiology, 5(2), 1 (2003).

5. E. M. Gonçalves, R. M. S. Cruz, M. Abreu, T. R. S. Brandao, C.L.M. Silva, Journal of Food Engineering, 93, 32 (2009). 
6. J. Novia, B.Pharm. Thesis, Department of Pharmaceutical Chemistry, University of Sumatera Utara, Medan, North Sumatera, Indonesia (2014).

7. S. Iqbal, U. Younas, S. Sirajuddin, K.W. Chan, R.A. Sarfraz, K. Uddin, International Journal of Molecular Sciences, 13(6),6651(2012).

8. M. G. Repetto, S. F. Llesuy, Brazilian Journal of Medical and Biological Research, 35(35), 523 (2002).

9. O. I. Aruoma, Mutation Research, 523, 9 (2003).

10. Y.J. Surh, L.R. Ferguson, Mutation Research, 523, 1(2003).

11. Ditjen POM, Indonesia Pharmacopoeia, Indonesia Department of Health, Jakarta, p.1067 (1995).

12. Ditjen POM, Materia Medika, Indonesia Department of Health, Jakarta, p.302, 321, 325 (1995).

13. N.R. Fransworth, J. Pharm. Sci., 55(3), 225 (1996).

14. J.B. Harbone, Metode Fitokimia, ITB, Bandung, p.47-102, 152-153 (1987).

15. I.I. Koleva, T.A. VanBeek, J.P.H. Linssen, A. de Groot, L.N. Estatieva, Phytochem. Anal.,13(8), 8 (2002).

16. S. Burali, A.R. Kulkarni, Res. J. Pharm. Biol. Chem. Sci., 4 Suppl 1, 340 (2013).

17. R. Rosidah, M. Yam, A. Sadiun, M. Asmawi, Pharm. Bio., 46, 616 (2008).

18. M.R. Ahmed, V.G. Sastry, N. Bano, S. Ravichandra, M. Raghavendra, Rasayan J. Chem., 4(2), 289 (2011).

19. R. Suthakaran, S. Kavimani, D. Venkappayya, F. Sakima, K. Suganthi, Rasayan J. Chem., 1(2), 263 (2008).

20. I. Iksen, M.Sc. Thesis, Department of Pharmaceutical Chemistry, University of Sumatera Utara, Medan, North Sumatera, Indonesia (2015).

21. I. Iksen, G. Haro, S.M. Sinaga. International Journal of ChemTech Research, 10(2), 99 (2017).

22. T. Yokozawa, C.P. Chen, E. Dong, T. Tanaka, G.I. Nonaka, I. Nishioka, Biochemical Pharmacology, 56, 213 (1998).

23. J.Y. Lee, W.I. Hwang, S.T. Lim, Journal of Ethnopharmacology, 93, 409 (2004).

24. N. Mehmod, M. Zubau, K. Rizwan, N. Rasool, M. Shahid, V.U. Ahmad, Iranian Journal of Pharmaceutical Research, 11(4), 1145 (21012).

25. A. Cakir, A. Mavi, C. Kazaz, A. Yildirim, O.I. Kufrevioglu, J. Chem., 30, 483 (2006).

26. M.B. Hossain, N.P. Brunton, C. Barry-Ryan, A.B. Martin-Diana, M. Wilkinson, Rasayan J. Chem.,1(4), 751 (2008).

27. A. Poedjiadi. Dasar-Dasar Biokimia, UI-Press, Jakarta, p.419 (1994).

[RJC-2011/2017] 